\title{
Concept of Leadership in the Ancient History and Its Effects on the Middle East ${ }^{i}$
}

\author{
Ercüment Yildirim
}

Department of History, Kahramanmaras Faculty of Arts and Sciences, Sutcu Imam University, Turkey

Copyright $\bigcirc 2016$ by authors, all rights reserved. Authors agree that this article remains permanently open access under the terms of the Creative Commons Attribution License 4.0 International License

\begin{abstract}
This paper is not written for political reasons. This study presents the perceptions about how the communities lived in the Middle East, which has been the center for religious, economic and political conflicts throughout history and how it has been ruled since the ancient times and how they can be ruled today. The aim of the study is to reveal the origins of the lifestyle of Middle Eastern people whom have only been gathered together under the hegemony of a leader. The Sumerian community, who has organized city kingdoms, formed the first legal state structure that puts the governor to the center and accordingly was the earliest monarchic kingdom system in history. By the invention of writing and the development of transportation, multinational states like the Akkadian Dynasty which ruled over large areas, has rapidly prospered. All the states which have been established in the Middle East following the Akkadian Dynasty were ruled by the monarchy system. The leaders, who hold the political and military power in the Middle East, had un-reachable place upon the people's minds. When compared with communities living in the other regions of the world, people of the Middle East are closer to the decentralizing thought system. This study, tries to give answers within the limits of the article, to such questions as "Who is a leader for the Middle Eastern people?", "What are the characteristics of a leader for the Middle Eastern people?" and "Can a leader be democratic?"
\end{abstract}

Keywords Middle East, Leadership, the Arabian Spring, Mesopotamia

\section{Introduction}

The geography in which three great civilizations of Ancient History, Mesopotamia, Anatolia and Egypt civilizations, rose development and dominated the history of humanity, is called the Middle East today. At the end of the 19th Century, French academicians used the expression, "Near East" for the lands under the domination of the Ottoman Empire, and Far East for China, Japan and the countries around them [1]. The expression of the Middle East was used in 1902 for the first time by Alfred Thayer Mahan (1840-1914), a naval officer and academician [2]. In this description, which were admitted in a short time, the geographical borders were not drawn and the description of the Middle East was shaped in accordance with the political borders of the countries. When we think about the Middle East in present, the borders which extend to Iran in the East, Egypt in the West, Turkey in the North and Yemen in the South, comes up in our minds. The geographical borders of the Middle East are thought as the Arabian Sea which is an extension of the Indian Ocean, Basra, Aden Gulf and the Red Sea in the South. East Mediterranean Sea and Aegean Sea in the West, Marmara Aegean Sea and The Black Sea in the North and the Caspian Sea in the East [3].

The Middle East has a very different cultural, ethnical and social structure in every period of history. The Middle East geography, which communities settled from the earliest times of the history, witnessed a lot of immigrations, which is comparable to no places in the world [4]. The greatest change in the Middle East found on the passing route of the continents, Africa, Asia and Europe known as the old world, occurred through the establishment of the states with the result that people adopted a settled life. "Fertile Crescent" forming a part of the Middle East, became the region in which the first agricultural economics developed and city states were established [5].

\section{Concept of Ruling in Ancient History}

The transition period to agricultural society, which is also named as "Neolithic Revolution", started in Mesopotamia. It is as this region was created for the birth of agriculture with its fruit trees, marshes and reed fields among limitless deserts extending over its sides [6]. The marsh areas were transformed into fertile fields with the channels through the settlement of Sumerians, the hardworking peasants, in this region. Moreover, according to a calculation made on a text dated 2500 B.C., eighty six fold products were obtained from a seed planted on a barley field. The small villages found on 
such fertile Mesopotamia lands developed in a short time and gave their place in agriculture cities [7].

The Sumerians solved the two important problems that they met on the way of urbanization with the help of clay which was abundantly found in the region. Firstly, they used adobe which was produced from clay both for construction of residence and temple because there wasn't any wood in great quantities. Therefore, they built cities formed by the houses whose surroundings were encircled with walls and had more than one room. The second important problem was to keep economic and religious records. They solved this by pressing reed on the wet clay tablets; in the end this led them to invent a new writing formed by signs after the pictures in the earlier times [8].

When villages of forty or fifty citizens, formed by five-six houses gave their places to great cities like Lagas composed of nineteen thousand, governing and being governed, problems took place in these villages. Since the people living in the villages that they established in the earlier periods of Neolithic Age had consanguinity with each other, a leader they chose among themselves, we can call him the clan leader as well, solved daily problems by taking the rules applied beforehand, that is to say, sustaining the tradition or easily enabling the rule of the people that he was responsible for [9].

As these villages founded with an agricultural purpose began to develop and urbanize and their populations started to reach a few thousand, the clan leadership began to give its place to kingdom, and the traditions to written laws [10]. A clan leader could sustain daily process through his simple orders to ones around him without needing any organization. In the vital cases related to all of the clan, it was possible to make a decision through a short interview made with the leaders of the clan. Since everybody participating in this meeting could express an opinion for the decisions to be made, later on there was no revolt or inconsistency [11]. Because the simple lives of these people that lived on agriculture and stockbreeding did not stick to the rules too much, the practices and beliefs they inherited from their ancestors were sufficient for the maintenance of life. The rules and beliefs were known by almost everyone and handed down to the generations after them [12].

When the populations of Sumerian villages came up five or six thousand, this system that can be applied for a few thousand people digressed from being useable for a population reaching over thousands. Moreover, the extant political, social and economic structure became out of use. Then the city public began to search a solution. Primarily a gabionade was built by means of common labour of the public in order to determine the borders of the city and enable its security [13]. To preserve these bulwarks that were constructed from adobe, a military class was established. Since in earlier periods everyone obtained production for their needs, they consumed what they produced. However, the yield suddenly increased through the application of agricultural production made by simple devices and animal force, and people began to produce much more than they needed. This surplus revealed the need to keep the product in stores or sell, so this made occupational groups need proper organizations in themselves like trade and storage and on which some people had to specialize [14].

This rapid development brought out two necessities with itself. The first of these was record keeping that this led to the invention of writing. Secondly, as the human relations developed with the emergence of different occupations and life styles, the rules coming from the tradition were not sufficient. Thus, every Sumerian city developed and recorded their own rules and therefore rules of law emerged. A short time ago the people leading a simple life suddenly specialized on different occupations. The life rapidly progressed in developed cities in which people stratified in various social classes primarily as military and religious, daily life was determined with the written law [15].

At this point, an authority was required to appear to establish and apply rules of law. Although the clan leader was the one elected to remain in office for a life time, he did not lead a different life from other clan individuals. Moreover, as he was tied to the rules that other individuals had to obey, he had no great superiority over the community [16]. When the villages began to develop, clan leaders started to see themselves as the sole source of the dominance, a new system began to dominate in cities, which we can define as a monarchy. Thus, the Sumerian cities formed by the transition of the agricultural society to settled life transformed into monarchic state structure, which had a political organization developed through writing, a professional army and well-organized trading structure, and at whose head there was a king [17].

While the government system in Mesopotamia was continuing in this way, a new civilization and therefore a new understanding of government developed around Nile River. The Nile valley became one of the fields that agricultural production was made in the easiest way in the world. The rise of the Nile River at particular times of the year made a very fertile mudflat spread out on the coast.

A very fertile harvest was made because of the seeds which were easily planted on this mudflat. In a short time this product surplus enabled many more people to live together and establish new villages along the river [18]. The rapid increase of the village populations caused the rise of small cities called Nom. From 4000 B.C. these states were brought up together in one administration. [19].

Egypt that fulfilled its political and social organization under a sole leader, accomplished to create great architectural works and cities contrary to state cities in Mesopotamia. At this point, the endurance of stone against adobe is also important. Furthermore, the fact that there was a leader to stimulate people in line with a purpose, and there was a centralized rule for centuries instead of political authorities that were suspended with the migration waves in Mesopotamia, played an active role in the formation of Egyptian civilization [20]. The leaders who gathered Egypt under themselves, namely pharaohs, saw the source of the dominance in their own existence. Moreover, they 
guaranteed not to be questioned by any means for their actions by declaring themselves as a god instead of making themselves gain a religious identity [21].

\section{The Forming of Concept of Leadership in Ancient History}

Until today, thousands of views were presented to make the definition of the concept of "Leadership" and many academic studies were made on this subject. In the last century, approximately 5000 studies were conducted and there were over 400 definitions [22]. In the historical process, the eminent philosophers of the Greek society in which the leadership concept was discussed and the government passed into other hands through despotic ways or election, tried to define the concept of leadership in order to systematize the governing logic. Socrates described the most significant quality of a leader as: "the ability to distinguish the good from the bad and to know what to do or not to do." [23]. According to Plato, the student of Socrates, the most basic condition to become a leader is to be a philosopher. Moreover by saying, "Either philosophers should be king or kings should be philosophers," Plato described the virtues of a philosopher makes him a king or a king should have the qualities of a philosopher. [24].

In Middle Eastern communities the thought related what qualities the leader should have come into prominence rather than the concept of leadership. There has always been an extant leadership structure in the mind of the Middle Eastern person since ancient ages. Thus, he has some basic expectations from the people who desire to govern him. Apart from these expectations, Middle Eastern communities separated the concepts of leader and governor. According to the perspective of these people, while the governor was trying to preserve status quo, the leader had to take the society or the state he governed further [25].

While the systematization of the concept of "Leadership" in modern sense arose in the 19th Century, the Western thinkers made definitions by using the internal dynamics of their own societies as a base. In spite of this, they supposed that the government philosophy of Middle Eastern communities that saw as backward was formed by the thought of "obedience based on fear." The fact that governmental development of Middle Eastern communities had a complicated social structure could not be explained so simply emerged in a later period [26]. So from the beginning of the 20th Century, many tests were made to define the concept of leadership in the Middle East. Despite many definitions made by the Orientalists, it isn't suitable to mention about a single type of leader or a leader profile that will contain all times for the definition of the Middle East. Here at this point, we will try to emphasize that how the content of the concept should be filled rather than the definition. Primarily, it is necessary to state that the coming of Islam served as a milestone for the change of government systems of Middle Eastern communities. Despite this, some elements of the government system which has its roots in ancient ages, various qualities asked from leaders continued in the same way after the coming of Islam even today [27].

When we have a look at the civilizations that the first city states composed, we see that the personal qualities which the leaders governing the society have determined the extant situation of the state. Yet as the institutionalization of bureaucracy did not completely occur, the fate of society depended upon the decisions and success of the leader. Therefore, when the states rapidly gained strength and developed under the powerful and skilled rulers, the death of these people carried the states in a process of fall [28]. State government which was fixed to the success of the leaders transformed into personalized ruler ships in time. Due to the personalized ruler ships, the intelligence courage and skill that the person in power has, and as a result of these, his prestige in society was admitted by people. The communities thought that the person who led them had more superior qualities than they had. From the earlier periods, the leaders tried to present this legality by either attributing themselves a religious leadership, or using violence, fear and pressure [29].

The rulerships provided by despotism were more short-lived than other legality systems. Because the rulerships formed by pressure and fear, may collapse with the sudden removal of the fear factor over the defeat of the leaders in a war or a disease. Even his death led the community's respect, mixed with fear, for him to continue for centuries. In the communities governed by despotism, it was expected from every individual to obey to the orders of the leader [30]. In these leadership systems, there was no concept such as dissenting or being against the state. These types of government systems are composed of people gathering around a purpose that the leader shows rather than a national or religious social structure. In the societies governed by the pressure element, the leaders have a continuous war system, because the most efficient way to hold people together is to convince them to fight together. Apart from this, the periods that despotic leaders appeared became the ones in which the countries were invaded by external powers. The desires of these leaders who emerged in emergency were fulfilled by society without questioning. The societies dominated by despotic leaders were generally the communities that had the same ethnic, religious and social structure [31].

From the ancient history, another source of the rulership is the phenomenon of religion. The leaders who had power did not avoid using religious beliefs to conduct the society they governed to a direction. Hence the leaders wanted to use the power that the religious beliefs had over the society, they did not allow other groups to direct this. In ancient history, we met two different examples of this [32].

The kings in Hittite State had a title of "Archpriest" as well as their ruling power. Thus, they attributed their decision to a divine power and presented themselves as a divine sublimity before the community. However, they met with some events that this case reversed as well. Especially 
in times of famine, depending upon drought or in epidemics, caused large amounts of deaths which were thought that the rulers of the state were punished by gods prevailed in society. Similarly, when the individuals of dynasty family killed each other, it was thought that they drew the rage of gods upon themselves. Therefore, the title of "Archpriest" of the Hittite kings mostly made the conduct of state easy and increased their dominance on the society [33].

The Egyptian pharaohs living in the same ages did not restrict their sublimity to become a priest of god but took on the source of the legality by declaring themselves a god. This case gave the pharaohs very great advantages. Firstly, it hindered the formation of a religious class that they had to struggle and prevented this class from fighting against them. Moreover, they transformed into a leader who spread fear over their community with the source of all favors to occur and evils. The Egyptian pharaohs constructed magnificent monuments for themselves by using their power. Because people working in construction of these structures, believed that they worked for their pharaoh who was a god, there was no objection [34].

In the same period, great and magnificent buildings were constructed in other states outside Egypt. The understanding of god-king that the Egyptian pharaohs created is a unique practice in terms of world history since it totally holds both the political and religious power. In this practice there was no possibility to object to the leader by any means or to question his decisions. As the pharaohs made the decisions in the name of themselves, that is to say, the god, the possibility for the religious class to question or criticize this was removed [35].

In ancient history another important power of the Middle Eastern world was the Assyria State. The Assyrian kings gathered all of the prestigious positions such as "Chief Justice," "Chief Commander," "Archpriest" like Hittite kings under their domination. However, when the Assyrians were compared to Hittites, Assyrians had a more developed bureaucracy system. The Assyrian kings were on the top of this bureaucratic ruling tradition. This bureaucratic tradition led to the formation of a bureaucracy class that was responsible for the continuation of the state as well as a dynasty class holding the rule. This case might prevent the Assyrian kings creating a dominance over the country or making everybody tied to the king unquestioningly as much as the Egyptian pharaohs [36].

The Middle East was not under the dominance of great states such as Hittite - Assyria and Egypt in every period of history. From the earliest periods of history, the Middle East was ruled by small states and the clans based on ethnic association as well. The ruling styles of these communities which are not based on a developed system as much as great states and bureaucracy generally continued depending upon the traditions coming from the past. These communities were governed by a ruler they elected among themselves. In this ruling system, the clan leaders should live as being tied to the rules coming from the tradition together with everybody living in the community. He could not make any decision and could not live out of these rules. That is to say, while a ruler could refuse to obey to the rules of law the community were subjected to, the clan leaders had to obey these traditions which did not transform into a written law. These leaders could not consider themselves outside and over the community. He had to live and behave like the ones who were under his dominance as an individual of the community [37]. The ones living in the community had to consider their leaders a person among themselves and had to admit that he was "the most superior person among the equal ones." Even though this understanding of ruling resembled the understanding of "Princeps", namely "The First Citizenship" in Rome in some ways, while this system in Rome was turned into a dictatorship in time, the leaders of small clans in the Middle East continued to live in this way for centuries [38].

The leader considered to be the first among the equal ones was required to create effects on others. Middle Eastern communities obeyed the ones who they considered more powerful or superior than themselves. To create this obedience culture, we mentioned above the methods the great states in Ancient History applied. But mostly, the leaders living in a consanguineous society needed to develop different methods to create an obedience culture on the people he lived together every day. The leaders linked the decision process that we can define as an authority to order on small communities to traditions mostly became connective. However, the leaders in new cases that the society never met made their own decisions. No matter how small the communities were, there was an advisory council mostly constituted by old people near the leader. This council helped in new decisions to be made by the leaders. In Middle Eastern communities that the leaders made firm and relentless decisions, made the ones govern fear and develop a sense of obedience mixed with fear. If the firm and relentless attitude operated fairly or the public considered the decisions of the leader fair, obedience transformed into a respect for the authority of the person in time [39].

As the leaders acceded with election gained power, they began to transform the family they had into a dynasty. The greatest difference on the way from community or clan leadership to the dynasty is succession system. In the death of the leaders who ruled small communities, notables of the community elected another leader commissioned for life and no individual in the community objected to this. In the dynasty systems, when the leader or the ruler died, his son or relative acceded in the state [40]. As the states developed their borders in the Middle East, the dynasty system began to be more dominant. While the dynasty system was suitable for the rule of great states, they found the rule of one person they elected among themselves for the small groups which were consanguineous. In the ancient history states bureaucracy that gradually began to develop had no meaning for small communities and clans. Because the small groups that suddenly made and applied decisions did not need to keep any record or correspond. However, when the communities united and became a state, bureaucrat who 
specialized on their subjects became an indispensable element of state government. As the leaders desired to hold the total power, they did not want the bureaucrats to be involved in state government. When the bureaucrats who were one of the basic elements of the formation of the state and their bureaucracy were compared to Rome and Greek world, they were very weak in the Middle Eastern states in Ancient History [41].

\section{Leadership in Today's Middle East}

The concept of leadership in today's Middle East was shaped after the First World War. Before the First World War, under the domination of the Ottoman Empire that continued roughly for five centuries, the ethnic and religious groups in the Middle East did not display any attempt to rebel. Both the thought that it was impossible to resist the great power of the Ottoman Empire and Ottoman's "Tolerance" policy combined with the understanding of justice prevailed in this. From the end of the 18th Century, the fact that the Ottoman Empire lost power against European states and the thought of nationalism that French revolution spreaded led the people to move against central government first in the Balkans then in the Middle East [42].

As the communities that lived under the Ottoman rule for a long time, lost almost total of the governmental and political organization, they could not be organized by themselves. At this point, the Western states tried to establish ruling organizations by conducting these communities in line with their own policies. With these ruling structures that did not occur in natural process and the rulers who did not move in accordance with the values of the communities, a permanent and balanced regulation was not possible. Today the bases of the conflicts inherited from periods that continue in the Balkans and the Middle East. On this subject it is necessary to mention about the leaders rather than how the ruling organizations are formed because the states in the Middle East had a ruling organization according to their leaders' willing [43].

In today's Middle East, when it is said leader, an oppressive, strict, who has a personalized power and focuses on preserving his rule at all costs will come to mind. From the 19th century the fact that the Middle East was the geography that the thoughts of freedom and democracy that spread in the whole world found support and were applied at the least was resulted from the qualities of the leaders in the countries. At this point, understand the perspective for the ruling structure of the leaders gained importance. Today the individuals of community who were used to be governed by democracy, consider the state an organization formed to make the society live comfortably and peacefully and in which every citizen is represented equally. However, today's Middle Eastern leaders see state as an organization that they create to sustain their legality. With a simpler expression, Middle Eastern leaders consider the fate of state as their own fate. On the base of the discourses of the leaders in the legalization of their rule it is the phenomenon that he rules the country the best and there is no country if he is absent. The communities to whom this black propaganda was performed were conditioned to see their leaders as indispensible [44].

It should not be thought that today's Middle Eastern leaders govern countries by themselves. The family or clan of the leader has a great importance in the state government. The leaders who appear before the public as the symbol of power and charisma share the state government among their families and relatives. These systems in which the close relatives of the head of the state behave like a "Dynasty Family" bring about much injustice and the waste of sources of the country. The public is classified according to the affinity to the leader. That is to say, while the communities that belong to the same ethnic, religious or denominational rank form the upper class of the society, other ethnic ranks and the ones who believe different religions and sects are involved in lower groups. The share of the richness's of the country is made in line with this system. This case led the ones living close to the leader or the head of the state to reach an enormous richness, and the great multitudes of people to live in poverty [45].

This governing structure and leadership profile that dominate today's Middle East bring about a continuous conflict environment. The leaders need a large network of enquiry to get the multitudes of people to rebel at any time as they have nothing to lose under control, and personal guards unit educated to protect himself from his public. In this governing structure, based on protecting himself and his power, the public is continuously repressed and punished out of law system. Thus, the people do not feel themselves safe and do not rely on their leader [46].

A particular importance was given to nobility derived from family in Arabian communities that composed the majority of Middle Eastern population. This case led the leaders to consider their family more superior than other multitudes of people forming the state. This formation we can call tribalism or micro nationalism, prevented society from adopting each other and becoming a "Nation." Right after the end of the domination of the Ottomans, Middle Eastern communities that were tried to be nationalized by the Western countries, could not enter in the process of being a "State" from "Tribalism" culture [47].

The western countries, who shared the region after the First World War formed ruling systems according to the boards that they formed. But in the two-pole world, after the end of the Second World War, Middle Eastern communities that were gradually saved from the mandate rule were directed by the same Western states to establish national states. These states composed outside natural formation process found themselves in the Cold War in a short time. During the Cold War, they first thought that the Arabian leaders clinged were Pan-Arabism. Because the leaders who realized that the tribalism thought was not enough to form a state tried to establish national states with Pan-Arabism ideology that they saw as a formation to embrace the whole 
society. During the establishment of national states, there was no significant development on behalf of democracy, only the leaders were contented with establishing councils to clear themselves [48].

During the Cold War, the Middle Eastern leader supported the USA or USSR in line with his interests. This case enabled the two great states to have an influence on the Middle East. Some leaders who blended Pan-Arabism and Socialism ideology with Islamic thought tried to reveal new governing models. The states that engaged with the USA tried to make the public admit a governing model we can define "Traditional Religious Monarchy." As these two governing systems were not derived from the internal dynamics of the Middle East, they were not accepted. In spite of this, the states in the Middle East along 50-70 years were governed by these two different systems. The USA became the dominant power of the world with the end of the Cold War, settled in the region to protect its interests based on petrol in the Middle East and tried to politically keep the states in the region under its hegemony. Nowadays the USA saw the continuous stay in the Middle East conflicted its interests began to retreat from the region after the second Gulf War [49].

Another event which gave the mentality of the Middle Eastern people a deep shock became the last decade called the internet age. The young population that rapidly increased in the Middle East began to be informed about various countries of the world and accept the thought that the despotic rule which their leader deemed proper was not their fate. The fact that great economic income they had was not shared fairly, they had no voice in state government and they were subjected to ethnic and religious discrimination, they were repressed under pressure and deterrence policy, other publics and nations lived in democracy fearlessly turned into a rebellion under the leadership of the youth. What the result will be of these rebellions called "The Arabian Spring" as a popular phrase and spread from one country to another is not definite. As a result of this movement, whether the Middle Eastern communities would reveal a new despotic leader or the governments, in which the conditions of democracy are enabled, did not become clear [50].

\section{Conclusions}

Middle East where the great part of developments of human beings common culture formed has been the geography where conflict and development lived together throughout history. Moreover, the greatest leaders of the history struggled to reign in these lands. In the eyes of the Middle Eastern communities living under the yoke of many leaders, heroes and rulers, a common leader type emerged and the qualities that they wanted this leader to have underwent little change from the ancient ages to these days. There is no great difference between the understanding of rule of today's governments in the Middle East and the ones of the states in Ancient History. The leaders, who rule the
Middle East countries at present, rule the country by putting forward their characteristic features as in the ancient times. Middle East countries are governed according to the willing of the ruling class instead of being governed by the features of the society. While the successful leaders dominated and governed the vast areas in a short time, the unskilled rulers coming after these leaders lost these lands and state authority in a short time. Throughout history, either there was an unattainable and powerful leader in the eyes of the society or holiness was given to the state in order to prevent the Middle Eastern communities governed by solid monarchy from revolting against the government. In these two cases it was aimed to provide the authority of the leader and the continuity of the state rather than the comfort and peace of the society.

There was a powerful, skilled, despotic when appropriate, fair in spite of all of these as an understanding coming from Ancient History to our age without any change in the mentality of the Middle Eastern communities. It is possible to see this understanding in Epic of Gilgamesh, the most important work of the Sumerian sources which give the first written documents of history. Gilgamesh is a wise and good warrior, and his despotic decisions lead the public to respect him rather than feeling fear. Gilgamesh, beside his adventurous travels, is seen as a powerful leader on the public. In the concept of governing in ancient Middle East which is formed during the period from the king to the heroes, the society has always accepted the entity of a leader to be apart from chaos.

The most significant quality coming from ancient history to today's Arabian heads of state without any change is that the leaders consider themselves more superior than every individual in society. It was not possible to be dominant over the Middle Eastern communities without this understanding of superiority. That is to say, people expected that the persons they would call leader who did not go after a person like themselves should be on the top of society in every respect. This case can be interpreted in the sense that these people will not respect the ones they do not fear. To explain this in more detail, if every soldier in battle field kills an enemy, it is required to kill many more enemies than all of them so that the soldiers will respect him. This understanding of thought achieved to come our day by beginning from the Sumerian city states. As the leaders knew this situation very well, they removed people that the society considered more successful in a subject than they were.

Another aspect that did not change from ancient ages to these days in the perception of leadership, is the thought that the leader should be the savior. That is to say, in the periods that the communities lived in abundance and welfare avoided falling under hegemony. However, when they were undergone an invasion of another society or state or exiled from their country, they began to search for a leader to gather them. The leaders appearing in these difficult conditions had great permanence. In the ruling concept that came up in the last century, as a virtue that democracy brought, an idea of the responsibility of the rulers against the people they ruled 
has spread. As the ruler had perceived the business that he made as a duty in democratic rulings, in the Middle East, this situation is thought as a right. The rulers have used the religious value or the military strength to legalize governing that saw as a right for them. Successful leader title is given to the ones who used these two powers in a balance, brought the economy in a good condition and kept the peace. The Middle Eastern communities governed with monarchy from the first periods of history were more prone to proceed after a leader rather than being governed with democracy because of their cultural and social structure. After the end of the Ottoman dominance in the Middle East, none of the leaders who took the lead, left their posts with election by following a democratic attitude. These leaders who took the lead thought that they would sustain these posts for life and even they tried to hand down their power to one of the individual from the family. These owners of power sought to protect their own interests either by monopolizing religion or by claiming that they dominated religious beliefs or they determined and removed the ones who were against themselves in society by means of a large intelligence of enquiry they created. The two cases were anti-democratic, and reduced the life quality of people; moreover they created a continuous source of disturbance in the country. Therefore, the Middle East became the centre of the continuous conflict. When world history is examined, the process passing from tribalism to empire, from empire to national states and then democracy has not been lived in the Middle East yet. As the Middle Eastern states did not get free of the tribalism thought in Ancient History, they could not adapt to democracy government. Thus, every individual in the Middle East had the desire of a very powerful leader rather than a democratic state. It is clear that this style of thought will not disappear easily in the next period.

\section{REFERENCES}

[1] Bonine, Michael (2012). Is There a Middle East?: The Evolution of a Geopolitical Concept. Stanford University Press, 22 - 24; Anderson, E. W. (2000). The Middle East: Geography and Geopolitics. Routledge Publishing, 11 - 14; Kort, Michael (2008). The Handbook of the Middle East. Twenty-First Century Books, 6 - 11.

[2] Brown, L. C. (2006). Diplomacy in the Middle East. I. B. Tauris Press, 17; Sorenson, D. S. (2010). Interpreting the Middle East. Westview Press, 61.

[3] Borthwick, Bruce (1980). Comparative Politics of the Middle East: An Introduction. Prentice Hall Publishing, 21 - 24; 21 24; Shlaim, Avi (1995). War and Peace in the Middle East: A Concise History. Penguin Books, 3 - 7; Mieroop, M. V. (2004). The Ancient Mesopotamian City. Oxford University Press, 9 - 12; Kamrava, Mehran (2011). The Modern Middle East: A Political History since the First World War. University of California Press, 3 - 5 .

[4] Lipiński, Edward (1995). Immigration and Emigration Within the Ancient Near East. Peeters Publishers, 221 - 233;
Bertman, Stephen (2003). Handbook to Life in Ancient Mesopotamia. Infobase Publishing, $62-67$.

[5] McIntosh, Jane (2005). Ancient Mesopotamia. Abc-Clio Publishing, 7 - 15; Kuiper, Kathleen (2011). Mesopotamia: The World's Earliest Civilization. Rosen Publishing, 32 - 34; Potts, D. T. (1997). Mesopotamian Civilization: The Material Foundations. Cornell University Press, $6-11$.

[6] Dejellis, Maria (1974). Agriculture and the State in Ancient Mesopotamia: An Introduction to Problems of Land Tenure. University of Pennsylvania Museum Publishing, Simmons, A. H. (2007). The Neolithic Revolution in the Near East: Transforming the Human Landscape. University of Arizona Press, 10 - 17; Postgate, Nicholas (1992). Early Mesopotamia: Society and Economy at the Dawn of History. Taylor \& Francis Publishing, $7-21$.

[7] Childe, Gordon (1990). Tarihte Neler Oldu? Çeviren: Mete Tunçay. Alan Yayıncılık, 66; Wildwood, Gretchen (2010). Ancient Mesopotamia Civilization. Rosen Publishing, 36 - 37; Nejat, K. R. (1998). Daily Life in Ancient Mesopotamia. Greenwood Publishing, 17 - 19; Gates, Charles (2003). Ancient Cities: The Archaeology of Urban Life in the Ancient near East and Egypt, Greece and Rome. Taylor \& Francis, 31 -33 .

[8] Kramer, Samuel (1963). The Sumerians: Their History, Culture and Character. University of Chicago Press, 73; Potts 1997, 91 - 97; McIntosh 2005, 199; Armstrong, Linda (2002). Mesopotamia. Lorenz Educational Press, 11.

[9] Snell, D. C. (2005). A Companion to the Ancient near East. John Wiley \& Sons Press, 391 - 394; Mieroop 2004, 197 203; McIntosh 2005, 129; Charvat, Petr (1993). Mesopotamia before History. Routledge Publishing, 196 - 205.

[10] Bederman, D. J. (2004). International Law in Antiquity. Cambridge University Press, 21 - 23; Kuiper 2011, 24; Sicker, Martin (2000). The Pre-Islamic Middle East. Greenwood Publishing, $23-24$.

[11] Algaze, Guillermo (2008). Ancient Mesopotamia at the Dawn of Civilization: The Evolution of an Urban Landscape. University Of Chicago Press, 40 - 42; Chavalas, M. W. (2006). Ancient near East: Historical Sources in Translation. John Wiley \& Sons Press, 169 - 175; Matthews, Roger (2003). The Archaeology of Mesopotamia: Theories and Approaches. Routledge Publishing, $182-185$.

[12] Bodley, J. H. (2011). Cultural Anthropology: Tribes, States, and the Global System. Rowman Altamira Publishing, 237 239; Lockard, C. A. (2011). Societies, Networks, and Transitions: A Global History to 1500. Cengage Learning, 34 - 36; Charvat 1993, $51-54$.

[13] Bertman 2003, 262 - 263; Hamblin, W. J. (2006). Warfare in the Ancient near East to 1600 BC: Holy Warriors at the Dawn of History. Routledge Publishing, 215 - 217; Maisels, C. K. (2001). Early Civilizations of the Old World: The Formative Histories of Egypt, the Levant, Mesopotamia, India and China. Routledge Publishing, 215.

[14] Mieroop 2004, 176 - 178; Bertman 2003, 274; Leech, B. C. (2007). Mesopotamia: Creating and Solving Word Problems. Rosen Publishing, 8; Bulliet, R.; Crossley P. (2001). The Earth and Its Peoples: A Global History. Wadsworth Publishing, $20-21$.

[15] Nejat 1998, 116; Potts 1997, 218 - 219; Charvat 1993, 216; Postgate 1992, 301; Schomp, Virginia (2004). Ancient 
Mesopotamia: The Sumerians, Babylonians, and Assyrians. Scholastic Publishing, 74 - 76.

[16] Bodley 2011, 239 - 240; Pollock, Susan (1999). Ancient Mesopotamia: The Eden That Never Was. Cambridge University Press, 21 - 24; Lloyd, A. B. (2010). A Companion to Ancient Egypt. John Wiley \& Sons Publishing, 54 - 57.

[17] Bottero, J.; Bahrani, Z. (1995). Mesopotamia: Writing, Reasoning, and the Gods. University of Chicago Press, $48-$ 50; Kuiper 2011, 150 - 153.

[18] Woods, M.; Woods, M. B. (1999). Ancient Agriculture: From Foraging to Farming. Twenty-First Century Books, 41 - 46; Challen, Paul (2004). Life in Ancient Egypt. Crabtree Publishing, 12 - 13; Brewer, D. J. (2012). The Archaeology of Ancient Egypt: Beyond Pharaohs. Cambridge University Press, 36 - 38; Bongo, K. A. (2008). Civilization and the Ancient Egyptians. Outskirts Press, $64-65$.

[19] Silverman, D. P. (2003). Ancient Egypt. Oxford University Press, 60 - 66; Strouhal, Evzen (1992). Life of the Ancient Egyptians. University of Oklahoma Press, 215 - 221; Burke, Edmund; Davis, D. K. (2011). Environmental Imaginaries of the Middle East and North Africa. Ohio University Press, 144 -146 .

[20] Wilkinson, T. A. H. (2001). Early Dynastic Egypt. Routledge Publishing, 112 - 115; Silverman 2003, 67; Lloyd 2010, 55.

[21] Frankfort, Henri (2011). Ancient Egyptian Religion: An Interpretation. Dover Publications, 31 - 39; Brier, R. M.; Hobbs, Hoyt (2008). Daily Life of the Ancient Egyptians. Greenwood Publishing, $13-21$.

[22] Rost, Joseph (1993). Leadership for the Twenty-First Century. Praeger Publishing, 7 - 19; McFarland, A. S. (1969). Power and Leadership in Pluralist Systems. Stanford University Press, 153 - 171; Erçetin, Şule (2000). Lider Sarmalında Vizyon. Nobel Yayın Dağıtım, 3.

[23] Polelle, M. R. (2007). Leadership: Fifty Great Leaders And The Worlds They Made. Abc-Clio Publishing, 89 - 91; Marturano, A.; Gosling, J. (2007): Leadership: The Key Concepts. Routledge Publishing, 125 - 126.

[24] Goethals, G. R.; Sorenson, G. L. (2007). The Quest for a General Theory of Leadership. Edward Elgar Publishing, 125 - 126; Cawthon, David (2002). Philosophical Foundations of Leadership. Transaction Publishers, 6 - 7; Manning, G.; Curtis, K. (2011). The Art Of Leadership. McGraw-Hill/Irwin Publishing, 96.

[25] Metcalfe, B.; Mimouni, F. (2013). Leadership Development in the Middle East. Edward Elgar Publishing, 12 - 17; Ciulla, J. B. (2004). Ethics, the Heart of Leadership. Greenwood Publishing, 7 - 10; Mieroop 2004, 25 - 27; Molchanov, M. Masciulli, J. (2009). The Ashgate Research Companion to Political Leadership. Ashgate Publishing, 37 - 38;

[26] Lindholm, Charles (2004). İslami Orta Doğu. İmge Kitapevi, 440 - 441; Ismael, T. Y. (2010). Governments and Politics of the Contemporary Middle East. Routledge Publishing, 3 - 9; Reid, J. J. (2000). Crisis of the Ottoman Empire: Prelude to Collapse, 1839-1878. Franz Steiner Verlag, 181 - 187.

[27] Metcalfe 2013, 12 - 22; Mottahedeh, Roy (2001). Loyalty and Leadership in an Early Islamic Society. I. B. Tauris Publishing, Kamrava 2011, $11-17$.

[28] Kramer 1963, 74 - 75; Johnston, Sarah (2007). Ancient
Religions. Harvard University Press, 167 - 169; Gates 2003, 31; Smith, A. D. (2008). The Cultural Foundations of Nations: Hierarchy, Covenant, and Republic. Blackwell Publishing, $56-57$.

[29] Beck, Hans (2013). A Companion to Ancient Greek Government. John Wiley \& Sons Publishing, 155 - 156; McIntosh 2005, 129; Orlin, L. L. (2007). Life and Thought in the Ancient near East. University of Michigan Press, $41-$ 43.

[30] Karlovsky, C. C. (1996). Beyond the Tigris and Euphrates: Bronze Age Civilizations. Ben-Gurion University of the Negev Press, 74 - 75; Kellerman, Barbara (1983). Leadership: Multidisciplinary Perspectives. Prentice-Hall Publishing, 56 - 59; Fairfield, Paul (2008). Why Democracy? State University of New York Press, $6-8$.

[31] Bratton, F. G. (1993). Myths and Legends of the Ancient near East. Barnes \& Noble Books, 18 - 21; Fleming, D. E. (2004). Democracy's Ancient Ancestors: Mari and Early Collective Governance. Cambridge University Press, 12 - 14.

[32] Mieroop 2004, 31 - 33; Holland, G. S. (2010). Gods in the Desert: Religions of the Ancient near East. Rowman \& Littlefield Publishers, 282 - 285; McIntosh 2005129 - 131.

[33] Bryce, Trevor (2003). Letters of the Great Kings of the Ancient near East: The Royal Correspondence of the Late Bronze Age. Routledge Publishing, 38 - 44; Raaflaub, K. A. (2006). War and Peace in the Ancient World. Blackwell Publishing, 102 - 103; Claessen, H. J.; Skalnik, Peter (1993). Erken Devlet. İmge Kitabevi, 113 - 118; Ekrem, Akurgal (1998). Anadolu Kültür Tarihi. Tübitak Yayınları, 117; Collins, B. J. (2008). The Hittites and Their World. Brill Press, 109.

[34] Strouhal 1992, 216 - 218; Brier 2008, 71 - 73; Dijk, Jacobus (1997). Essays on Ancient Egypt on Honour of Herman Te Velde. Brill Press, 251 - 254; Allen, J. P. (2010). Middle Egyptian: An Introduction to the Language and Culture of Hieroglyphs. Cambridge University Press, 33 - 34.

[35] McNeese, Tim (1999). The Ancient World. Milliken Publishing, 17 - 18; Wilson, J. A. (1956). The Culture of Ancient Egypt. University Of Chicago Press, 69 - 71; Silverman, D. P.; O'Connor, D. B. (1995). Ancient Egyptian Kingship. Brill Press, 21 - 23; Miller, G. P. (2011). The Ways of a King. Vandenhoeck \& Ruprecht Publishing, 99-103.

[36] Sayce, A. H. (2008). Babylonians and Assyrians: Life and Customs. Kessinger Publishing., 169 - 172; Holloway, S. W. (2001). Assur Is King! Assur Is King!: Religion in the Exercise of Power in the Neo-Assyrian Empire. Brill Academic Publishing, 219 - 220; Yoffee, Norman; Clark, J. J. (1994). Early Stages in the Evolution of Mesopotamian Civilization: Soviet Excavations in Northern Iraq. University of Arizona Press, 259 - 260.

[37] Shenkar, Oded; Punnett, B. J. (2004). Handbook for International Management Research. University of Michigan Press, 305 - 307; Metcalfe 2013, 138; Khoury, P. S.; Kostiner, Joseph (1991). Tribes and State Formation in the Middle East. University of California Press, 32 - 34; Chatty, Dawn (2005). Nomadic Societies in the Middle East and North Africa: Entering the 21st Century. Brill Academic Publishers, 33 37.

[38] Derks, Ton; Roymans, Nico (2009). Ethnic Constructs in Antiquity: The Role of Power and Tradition. Amsterdam 
University Press, 196 - 197; Shaw, B. C. (1995). Rulers, Nomads, and Christians in Roman North Africa. Variorum Publishing, $25-29$.

[39] Finer, S. E. (1997). The History of Government from the Earliest Times: Ancient Monarchies and Empires. Oxford University Press, 168 - 172; Claessen, H. J.; Velde, P. V. (1988). Early State Dynamics. Brill Academic Publishing, 280 - 281; Bodley 2011, 219 - 220.

[40] Khoury 1991, 111 - 113; Metcalfe 2013, 157 - 161; Bates, D. G.; Rassam, Daniel (2001). Peoples and Cultures of the Middle East. Prentice Hall Publishing, 152 - 156.

[41] Khoury 1991, 99 - 100; McIntosh 174; Yoffee 1994, 47 - 52; Brough, Charles (2010). The Last Civilization. Trafford Publishing, $65-67$.

[42] Pappe, Ilan (2010). The Modern Middle East. Routledge Publishing, 15 - 16; Akgündüz, Ahmed; Öztürk, Said (2011). Ottoman History: Misperceptions and Truths. IUR Press, 432 $-432$.

[43] Hourani, A. H. (1993). The Modern Middle East. University of California Press, 23 - 27; Sicker, Martin (2001). The Middle East in the Twentieth Century. Greenwood Publishing, 1 - 5; Stewart, D. J. (2012). The Middle East Today: Political, Geographical and Cultural Perspectives. Routledge Publishing, 3 - 23; Sluglett, Peter (2008). The Urban social history of the Middle East, 1750-1950. Syracuse University Press, $101-103$

[44] Peretz, Don (1994). The Middle East Today. Praeger Publishing, 135 - 137; Kamrava 2011, 303 - 310; Metcalfe 2013, $78-85$; Khoury 1991, $74-82$.

\footnotetext{
${ }^{i}$ This article is the extended version of the summary that was presented and published as a paper at the conference in the University of Marmara in Istanbul on June 19-21, 2013 which held at the European Conference on Social Science Research.
}

[45] Wingate, Brian (2004). Saddam Hussein. Rosen Publishing, 26 - 32; Darra, S. M. (2007). Hosni Mubarak. Infobase Publishing, 60 - 66; Reed, Jennifer (2007). The Saudi Royal Family. Infobase Publishing, 23 - 30; Hourani 1993, 593 597.

[46] Fawcett, Louise (2009). International Relations of the Middle East. Oxford University Press, 228 - 229; Lockard 2011, 654; Korany, Bahgat (2011). The Changing Middle East: A New Look at Regional Dynamics. The American University in Cairo Press, $92-93$.

[47] Khoury 1991, 294 - 297; Brynen, Rex (1995). Political Liberalization and Democratization in the Arab World: Theoretical Perspectives. Lynne Rienner Publishing, 67 - 71.

[48] Roy, Olivier (2009). The Politics of Chaos in the Middle East. Columbia University Press, 79 - 87; Curtis, Michael (1986). The Middle East: A Reader. Transaction Publishers, 21 - 33; Brown 2006, 109 - 111; Anderson 2000, 298 - 301.

[49] Ashton, N. J. (2007). The Cold War in the Middle East: Regional Conflict and the Superpowers, 1967-73. Routledge Publishing, 1 - 12; Vatikiotis, P. J. (1997). The Middle East: From the End of Empire to the End of the Cold War. Routledge Publishing, 44 - 59; Milton-Edwards, Beverley; Hinchcliffe, Peter (2007). Conflicts in the Middle East since 1945. Routledge Publishing, 36 - 51.

[50] Panara, Carlo; Wilson, Gary (2013). The Arab Spring: New Patterns for Democracy and International Law. Martinus Nijhoff Publishers, 77 - 98; Manhire, Toby (2012). The Arab Spring: Rebellion, Revolution, and a New World Order. Guardian Books. Bradley, J. R. (2012). After the Arab Spring: How Islamists Hijacked The Middle East Revolts. Palgrave Macmillan Publishers. 